\title{
Adverse reactions to medication on a coronary care unit
}

\author{
RODNEY H. FALK* \\ B.Sc., M.R.C.P. (U.K.) \\ Department of Medicine, Brook General Hospital, London, S.E. 18
}

\begin{abstract}
Summary
In a prospective survey of treatment on a coronary care unit $23.6 \%$ of patients who received medication had one or more side effects. In several cases these were severe enough to cause marked deterioration of the patient's clinical status. Whilst antiarrhythmic therapy is an integral part of modern coronary care its potential hazards should be recognized, particularly in the elderly patient.
\end{abstract}

\section{Introduction}

Since the advent of coronary care units (CCU), the hospital mortality from ventricular fibrillation has fallen. This is due not only to rapid defibrillation with direct current shock but also to the treatment of arrhythmias likely to predispose to ventricular fibrillation. However, the constant cardiac monitoring, leading as it does to early treatment with anti-arrhythmic medication, will naturally expose patients to drugs they may not otherwise have received. Whilst this is aimed at benefiting the patient the likelihood of adverse drug reactions will increase. If severe, these may be detrimental to the patient, perhaps in some cases outweighing the benefit of therapy. Despite studies showing a relatively high incidence of side effects of medication in patients in general hospital wards, no similar study has been undertaken in the CCU. The present survey was designed to study the pattern of drug use on such a unit and to record the incidence of adverse reactions to therapy and their effect on the patient.

\section{Patients and methods}

All patients with proved acute myocardial infarction admitted to the 6-bed CCU of the Brook General Hospital were prospectively studied. The survey spanned a 6-month period. Myocardial infarction was defined as chest pain with associated enzyme rise and electrocardiographic changes. There was no age limit for admission to the CCU and it was not the policy to give routine prophylactic antiarrhythmic medication. On admission the

\footnotetext{
*Present address: Department of Nutrition, Harvard School of Public Health, Boston, MA, 02115, U.S.A.
}

clinical condition of the patient was recorded with $\vec{\sigma}$ smoking history, present medication and ECG site of infarction. All antiarrhythmic medication $\frac{0}{3}$ prescribed was recorded as well as the indication for the drug and the patient's response. The latter was $O$ I divided into 3 categories - no response, desired $f$ response (e.g., partial or complete suppression of ${ }_{\infty}^{\circ}$ arrhythmia) or side effects.

Side effects were subdivided as follows:

(a) Mild - non-cardiac with tolerable patient discomfort, e.g. mild dyspepsia, rash.

(b) Moderate-more severe non-cardiac side $\stackrel{\mathbb{D}}{\mathbb{Q}}$ effects usually necessitating stopping medication, $\frac{\mathbb{D}}{\mathcal{B}}$ e.g. severe dyspepsia, or transient cardiac effects of potentially serious nature, e.g. transient bradycardiळ. -

(c) Severe - potentially life-threatening or effecess $\vec{\theta}$ likely further to impair cardiac function, e.g. pud monary oedema, marked hypotension, severe co fusion.

Non-antiarrhythmic therapy and procedures such as temporary transvenous cardiac pacing were also recorded in a similar manner.

\section{Results}

Eighty-nine patients with proved myocardial infarction were admitted during the period studied. Fifty-seven $(64 \%)$ were aged $<65$ years and $32 \%$ $(36 \%)>65$ years. The overall mortality during the $\frac{3}{3}$ total hospital stay was $12 \cdot 4 \%$. All but 2 of those patients died on the CCU. Four patients <653. years old $(7.0 \%)$ died, compared with $7(21.9 \%)$ aged $>65$ years. Whilst on the CCU, $42(47 \cdot 2 \%)$ patients received at least one dose of an antiarrhyth-o mic drug. There was no significant difference in the proportion of younger patients receiving therapy음 compared with those of 65 years $(45 \cdot 6 \% v .50 \%)$. A total of 65 antiarrhythmic drugs were given to these $\sigma$ patients, a mean of 1.55/patient. Younger patients $N$ received significantly fewer drugs than did older $N$ patients (1.35 v. 1.88 drugs/patient).

\section{Indications for therapy}

Ventricular ectopic beats were treated only if more $\stackrel{\Phi}{\Phi}$ frequent than $5 / \mathrm{min}$ or if they met any of the other Lown criteria (Lown et al., 1967). Lignocaine was the 
drug of first choice and was used in 24 patients, of whom 19 had asymptomatic ectopic activity. If ventricular ectopic activity persisted despite lignocaine, or recurred on stopping the lignocaine at 24 $36 \mathrm{hr}$ oral disopyramide was commonly prescribed, 8 patients receiving this drug.

Beta-blocking agents were used in 9 patients, predominantly for regular supraventricular arrhythmias, or persistent sinus tachycardia in the absence of cardiac failure. Digoxin was used in only 6 patients, the indications being atrial fibrillation with fast ventricular response or cardiac failure with cardiomegaly.

For bradyarrhythmias, atropine was the drug of first choice. All 11 patients who received atropine had symptomatic bradycardia $(<55 / \mathrm{min})$ due to heart block or sinus bradycardia, with a systolic blood pressure below $90 \mathrm{mmHg}$.

Other antiarrhythmic drugs used occasionally as second-line agents included mexiletine, verapamil and phenytoin. The specific indications for therapy in individual patients experiencing side effects are recorded in Tables 2 and 3.

\section{Effect of therapy}

Thirteen of the 65 drugs $(20 \%)$ produced side effects. Thirty-one $(47.7 \%)$ led to improvement in the patient's condition and $21(32.3 \%)$ had no effect. A comparison of the 2 age groups (Table 1) shows the similarity of response in both groups. The side effects of antiarrhythmic medication are shown in Table 2. Seven patients experienced adverse reactions to other medication as shown in Table 3. Combining the data of Tables 2 and 3, 21 side effects occurred in 17 patients-an incidence of $19.1 \%$ of all patients. Excluding the 14 patients who received no medication in any form whilst on the CCU, the incidence of side effects becomes $23.6 \%$ of those patients receiving some form of drug treatment. Reference to the tables shows that whilst the older patients were not subject to a higher incidence of side effects, those that they did experience tended to be more severe.

\section{Discussion}

Despite the higher mortality of elderly patients in this study, the incidence of side effects was no higher than younger patients when considered in relation to the total number of medications prescribed.

TABLE 1. Results of antiarrhythmic therapy in the 2 age groups. Figures in brackets indicate percentage

\begin{tabular}{llll}
\hline & $<65$ years & $>65$ years & \multicolumn{1}{c}{ Total } \\
\hline No benefit & $10(28 \cdot 6)$ & $11(36 \cdot 6)$ & $21(32 \cdot 3)$ \\
Improved & $18(51 \cdot 4)$ & $13(43 \cdot 4)$ & $31(47 \cdot 7)$ \\
Side effect & $7(20)$ & $6(20)$ & $13(20)$ \\
& 35 & 30 & 65 \\
\hline
\end{tabular}

TABLE 2. Side effects of antiarrhythmic medication

\begin{tabular}{|c|c|c|c|c|c|}
\hline Patient No. & Age & Drug & Indication & Side effect & Classification \\
\hline \multicolumn{6}{|l|}{ (a) Over 65} \\
\hline $\begin{array}{l}2 \\
3\end{array}$ & $\begin{array}{l}72 \\
72\end{array}$ & $\begin{array}{l}\text { Isoprenaline } \\
\text { Digoxin }\end{array}$ & $\begin{array}{l}\text { Heart block bradycardia } \\
\text { Atrial fibrillation }\end{array}$ & $\begin{array}{l}\text { Ventricular tachycardia } \\
\text { Severe, prolonged } \\
\text { vomiting }\end{array}$ & $\begin{array}{l}\text { Severe } \\
\text { Moderate }\end{array}$ \\
\hline 3 & 72 & Propranolol & $\begin{array}{l}\text { Uncontrolled atrial } \\
\text { fibrillation }\end{array}$ & $\begin{array}{l}\text { Intractable left } \\
\text { ventricular failure }\end{array}$ & Severe \\
\hline 3 & 72 & Lignocaine & $\begin{array}{l}\text { Frequent ventricular } \\
\text { ectopic beats }\end{array}$ & Coma & Severe \\
\hline 6 & 75 & Disopyramide & $\begin{array}{l}\text { Ventricular ectopic } \\
\text { beats }\end{array}$ & $\begin{array}{l}\text { Left ventricular } \\
\text { failure }\end{array}$ & Severe \\
\hline 6 & 75 & $\begin{array}{l}\text { Mexiletine } \\
\text { (oral) }\end{array}$ & $\begin{array}{l}\text { Ventricular ectopic } \\
\text { beats }\end{array}$ & $\begin{array}{l}\text { Severe gastrointestinal } \\
\text { disturbance }\end{array}$ & Moderate \\
\hline 53 & 65 & Lignocaine & $\begin{array}{l}\text { Ventricular ectopic } \\
\text { beats }\end{array}$ & $\begin{array}{l}\text { Hypotension and } \\
\text { vomiting }\end{array}$ & Moderate \\
\hline \multicolumn{6}{|l|}{ (b) Under 65} \\
\hline 22 & 62 & Verapamil & $\begin{array}{l}\text { Supraventricular } \\
\text { tachycardia }\end{array}$ & $\begin{array}{l}\text { Hypotension and left } \\
\text { ventricular failure }\end{array}$ & Severe \\
\hline 41 & 52 & $\begin{array}{l}\text { Disopyramide } \\
\quad \text { (oral) }\end{array}$ & $\begin{array}{l}\text { Ventricular ectopic } \\
\text { beats. }\end{array}$ & $\begin{array}{l}\text { Persistent systolic } \\
\text { BP below } 100 \text { until } \\
\text { drug stopped }\end{array}$ & Moderate \\
\hline 57 & 54 & Digoxin & Cardiac failure & $\begin{array}{l}\text { Bradycardia and } \\
\text { Wenckebach pheno- } \\
\text { menon }\end{array}$ & Moderate \\
\hline 67 & 56 & Disopyramide & $\begin{array}{l}\text { Frequent, multifocal } \\
\text { ventricular ectopic } \\
\text { beats. }\end{array}$ & $\begin{array}{l}\text { (a) Acute retention } \\
\text { (b) Hypotension and } \\
\text { severe left } \\
\text { ventricular failure }\end{array}$ & Severe \\
\hline $\begin{array}{l}73 \\
84\end{array}$ & $\begin{array}{l}62 \\
52\end{array}$ & $\begin{array}{l}\text { Propranolol } \\
\text { Lignocaine }\end{array}$ & $\begin{array}{l}\text { Persistent chest pain } \\
\text { Ventricular ectopic beats }\end{array}$ & $\begin{array}{l}\text { Nausea } \\
\text { Slurring of speech }\end{array}$ & $\begin{array}{l}\text { Mild } \\
\text { Mild }\end{array}$ \\
\hline
\end{tabular}


TABLE 3. Side effects of other treatment prescribed on coronary care unit

\begin{tabular}{|c|c|c|c|c|c|}
\hline Patient No. & $\begin{array}{c}\text { Age } \\
\text { (years) }\end{array}$ & Treatment & Indication & Side effects & Classification \\
\hline (a) $\underset{31}{\text { Over }} 65$ & 69 & Glyceryl trinitrate & Chest pain & $\begin{array}{l}\text { Faintness and transient } \\
\text { hypotension }\end{array}$ & Moderate \\
\hline 35 & 72 & $\begin{array}{l}\text { Temporary pacing } \\
\text { wire }\end{array}$ & $\begin{array}{l}\text { Sinus node } \\
\text { dysfunction }\end{array}$ & Staphylococcal septicaemia & Severe \\
\hline 65 & 70 & Frusemide & Cardiac failure & Skin rash & Mild \\
\hline 72 & 71 & Thyroxine & $\begin{array}{l}\text { Newly diagnosed } \\
\text { myxoedema }\end{array}$ & Confusion, severe arrhythmia & Severe \\
\hline $\begin{array}{c}\text { (b) Under } 65 \\
17\end{array}$ & 44 & Frusemide & Cardiac failure & $\begin{array}{l}\text { Hypokalaemia }(\mathrm{K}+=2 \cdot 2) \\
\rightarrow \text { ventricular ectopic activity }\end{array}$ & Moderate \\
\hline $\begin{array}{l}64 \\
82\end{array}$ & $\begin{array}{l}57 \\
52\end{array}$ & $\begin{array}{l}\text { Glyceryl trinitrate } \\
\text { Glyceryl trinitrate }\end{array}$ & $\begin{array}{l}\text { Chest pain } \\
\text { Chest pain }\end{array}$ & $\begin{array}{l}\text { Sinus arrest } \rightarrow \text { syncope } \\
\text { Marked but transient } \\
\text { hypotension }(60 / ?)\end{array}$ & $\begin{array}{l}\text { Severe } \\
\text { Moderate }\end{array}$ \\
\hline
\end{tabular}

However, since elderly patients received more drugs their chances of experiencing an adverse reaction were higher. Coupled with the tendency for more severe reactions to occur in the older group it may be stated that these patients are at a greater risk of moderate and severe side effects. Nevertheless the younger patients were not immune and the overall incidence of adverse reactions of $23.6 \%$ indicates the need for particular care on the part of the physician when prescribing on the coronary care unit.

Although no similar previous survey of medication on the CCU is available there have been several studies of side effects of medication in different hospital environments. Hurwitz and Wade (1969) found that $10 \cdot 2 \%$ of all hospital patients receiving medication experienced drug reactions and they considered $80 \%$ of these to be of moderate severity, necessitating treatment and/or prolonging hospital stay by at least one day. Patients on medical wards constituted approximately half their total patient population and the incidence of adverse reactions in this group was $16.4 \%$ compared with only $3.2 \%$ of surgical patients. Despite this high incidence, the authors conclude that 'such an incidence of reactions to drugs may pass almost unnoticed in the hospital community unless a special survey is undertaken'. A similar statement is made by Buchanan and Cane (1978) who studied drug utilization in a general intensive care unit and found the mean number of drugs prescribed per patient was 7 . There was an overall mortality of $24.5 \%$. They point out the vast potential for drug interactions in such circumstances and comment that although several cases of iatrogenic diseases were noted, probably many more such instances passed unnoticed. The CCU probably lies somewhere between the general medical ward and the intensive care unit with respect to drug utilization and severity of illness, and hence to adverse reactions. Allowing for the difference in patient composition and prescribing habits between a general medical ward and $\mathrm{CCU}$, the incidence of adverse reactions in the present study is in the range $\circlearrowleft$ one might expect from the work of Hurwitz and $\infty$ Wade.

Whilst most of the side effects in the CCU patients 윽 are related to hypotension, cardiac failure or non- cardiac manifestations, one should be aware of the potential paradoxical effects of antiarrhythmic $\underset{\mathbb{\Phi}}{\mathbb{Q}}$ medication. In a study of cardiac patients undergoing $\frac{\Phi}{3}$ acute drug testing with a variety of oral antiak rhythmic drugs (Velebit et al., 1979), 12\% had exacerbation of their arrhythmia. These patien predominantly had either chronic ischaemic heap̄i disease or non-ischaemic heart disease. In the setting of acute myocardial infarction where rhythm disturbances tend to fluctuate more than in the chronic stage, the physician may attribute a deterioration in

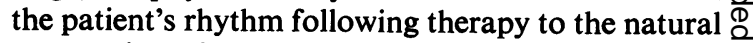
progression of the arrhythmia coupled with a failure $\overrightarrow{\vec{P}}$ of treatment, rather than seeing the therapy as the $\frac{3}{3}$ causative factor in the deterioration. A careful $\vec{\partial}$ assessment of the situation will aid in deciding whether to continue with drug therapy or to discontinue and utilize alternative therapy. The negative 3 inotropic effects of many antiarrhythmic medications may cause diuretic-resistant cardiac failure in the 3 susceptible patient which may be wrongly attributed $\delta$ to cardiogenic shock (Resnekov, 1978). Withdrawal of disopyramide in case number 6 (Table 2), led to 윽 rapid resolution of left ventricular failure previously poorly responsive to high dose diuretics.

It has been argued that if the benefits of modern drug therapy are to be exploited, the occurrence of $\%$ adverse reactions to drugs has to be accepted $\tilde{O}$ (Hurwitz and Wade, 1969). However, one should $\underset{\omega}{N}$ constantly attempt to reduce the incidence of such 0 reactions in order to reduce patient morbidity and, 0 possibly, mortality. Despite the fact that no patient $\frac{}{\Phi}$ in the present study had a reaction which could be $\stackrel{?}{?}$ unequivocally related to their subsequent death, $\square$ 
those patients who have severe reactions are at risk of extending their infarct size owing to the hypotension or arrhythmia provoked by the drug. Since this study did not examine mortality after hospital discharge, one cannot determine the long-term effects but they are likely in some cases to be detrimental.

A prime duty of the physician is 'to do no harm' but at times he will have to weigh up the potential good of a drug against the harm it may cause. Necessary therapy should not be withheld from the patient on the coronary care unit, but caution should be exercised particularly when prescribing for the elderly. Perhaps, by bearing this in mind, the trend towards the ICCU (intensive coronary care unit) will move towards the CCCU (the conservative coronary care unit).

\section{References}

Buchanan, N. \& CANe, R.D. (1978) Drug utilization in a general intensive care unit. Intensive Care Medicine. 4, 75.

HuRwitz, N. \& WADE, O.L. (1969) Intensive hospital monitoring of adverse reactions to drugs. British Medical Journal, 1, 531.

Lown, B., Fakhro, A.M., Hood Jr, W.B. \& Thorn, G.W. (1967) The coronary care unit: new perspectives and directions. Journal of the American Medical Association, 199, 188.

Resnekov, L. (1978) Cardiogenic shock. British Journal of Hospital Medicine, 20, 232.

Velebit, V., Podrid, P.J., Graboys, T.B. \& Lown, B. (1979) Aggravation of ventricular arrhythmia by antiarrhythmic drugs. American Journal of Cardiology, 43, 359. 